УДК 340.1

\author{
Тетяна Іванівна Тарахонич, \\ стариий науковий співробітник відділу \\ теорії держави і права Інституту держави і права \\ ім. В.М. Корецького НАН Украӥни, \\ кандидат юридичних наук
}

\title{
ПРАВОВИЙ МОНІТОРИНГ ЯК ОДИН ІЗ ШЛЯХІВ ВДОСКОНАЛЕННЯ ПРАВОВОГО РЕГУЛЮВАННЯ
}

Постановка проблеми. Системні зміни, що відбуваються не лише в суспільстві, а й в державі, в різних сферах суспільного життя, в правовій системі, вимагають досконалого та якісного правового регулювання. Виникнення нових та перегляд існуючих вимог до якості та досконалості правового регулювання потребують переосмислення усталених положень вітчизняної юридичної думки щодо сукупності чинників, які впливають на цей процес.

Досконале та дієве законодавство, в якому відсутні колізії та суперечності, прогалини, застарілі норми, що не відповідають реаліям сьогодення, є важливим чинником рівня розвитку суспільства та держави. На жаль, аналіз стану правового регулювання свідчить про збільшення кількісного, а не якісного показника нормативно-правових актів, відсутність чи недієвість механізмів реалізації тих актів.

Одним із шляхів удосконалення правового регулювання є здійснення правового моніторингу на різних стадіях правового регулювання та дії його механізму. Правовий моніторинг сприяє ретельному аналізу та експертній оцінці нормативно-правових актів, надає можливість виокремити пріоритетні напрями здійснення регулятивного впливу, допомагає передбачити можливі наслідки дії тих чи інших актів, впливає на досягнення балансу між процесом прийняття відповідного акта та його реалізацією на практиці.

Зазначене свідчить про актуальність даної проблематики, необхідність пошуку нових підходів щодо визначення поняття правового моніторингу, формування його доктрини та можливості його використання в правовій сфері.

Аналіз останніх досліджень та публікацій. Правовий моніторинг $\epsilon$ предметом аналізу зарубіжних та вітчизняних вчених, зокрема це праці таких вчених, як: А. Артамонова, О. Зайчука, В. Косовича, Н. Нижник, I. Онищука, Н. Оніщенко, І. Шутака тощо.

Метою статті є з'ясування теоретичних основ розуміння сутності правового моніторингу як одного із шляхів вдосконалення правового регулювання та забезпечення дієвості його механізму.

Основні результати дослідження. Правовий моніторинг є важливим інструментом пошуку організаційно-правових та інституційних засобів забезпечення ефективності правового регулювання, важливим напрямом досягнення дієвості законодавства та правової системи загалом. Це зумовлює необхідність грунтовного аналізу правового моніторингу на загальнотеоретичному рівні.

Аналіз літературних джерел дає підстави стверджувати, що правовий моніторинг можна розглядати як: правову категорію, як різновид діяльності, як структурно-інформаційний інститут.

Розглядаючи правовий моніторинг як юридичну категорію, слід підкреслити, що вона має як доктринальну, так і практичну складову. На доктринальному рівні правовий моніторинг розглядається як один із методів наукового пізнання, що характеризується необхідністю здійснення аналізу правової сфери шляхом використання відповідних засобів та прийомів, формування відповідної методики його проведення. Практична складова правового моніторингу включає в себе етапи спостереження, аналізу, узагальнення та передбачає використання різноманітних способів та прийомів збору та обробки інформації, що свідчить про його прогностичну спрямованість.

Так, Н. Р. Нижник, розглядаючи моніторинг законодавства на практичному рівні, зазначає, що це систематична, комплексна діяльність органів влади, наукових установ, інститутів громадянського суспільства з оцінки, аналізу, узагальнення результатів дії норм права та прогнозування розвитку законодавства. Поряд з цим, вчена виокремлює об’єкти моніторингу, а саме: закони 
або інші нормативні акти; стан дотримання прав людини (за сферами або певних категорій суб'єктів); функціонування гілок влади в аспекті права [1, с. 51].

Слід погодитися 3 думкою I. I. Онищука, що правовий моніторинг $є$ інструментом динаміки права, який повинен супроводжувати всі елементи механізму правового регулювання: від формування нормативної бази до забезпечення законності та правопорядку. Загальним об'єктом правового моніторингу на національному рівні виступає вся правова система, усі правові явища у межах кордонів держави, усі елементи механізму правового регулювання [2, с. 59].

Заслуговує на увагу позиція І. Д. Шутака, який підкреслює, що у сучасній правовій доктрині зароджується поняття правового моніторингу як систематичної, комплексної діяльності, спрямованої на спостереження, аналіз, оцінювання чинного законодавства і практики його застосування, 3 метою посилення ефективності законодавства та його подальшого прогнозування. Об'єктом правового моніторингу може бути будь-який нормативно-правовий акт і практика його застосування [3, с. 20].

Ю. О. Тихомиров розглядає правовий моніторинг як новий структурно-інформаційний інститут правового регулювання, що використовується переважно в механізмі правозастосування для його аналізу, оцінки та вдосконалення [4, с. 351].

Оскільки правовий моніторинг може здійснюватись в різних сферах суспільних відносин, слід говорити про галузевий правовий моніторинг. Так, наприклад, ряд вітчизняних вчених, аналізуючи правовий моніторинг навколишнього природного середовища, екологічний моніторинг, моніторинг довкілля, підкреслюють, що це система спостереження за станом навколишнього природного середовища [5, с. 484].

Поряд 3 цим, I. І. Онищук підкреслює, що правовий моніторинг можна розглядати на різних рівнях наукового пізнання, а саме як метод отримання певних відомостей щодо якості та ефективності правового регулювання; як вид правового контролю, як комплексний інститут саморегуляції правової системи [6, с. 92].

На нашу думку, правовий моніторинг - це один із методів наукового пізнання, що спрямований на спостереження, збір та аналіз інформації в правовій сфері з метою забезпечення дієвості та ефективності нормативного масиву та прогнозування його розвитку в майбутньому.

Розглядаючи правовий моніторинг як метод наукового пізнання, необхідно підкреслити можливість використання таких прийомів, як спостереження, аналіз зібраної інформації, узагальнення результатів 3 можливим прогнозом перспектив розвитку певного явища чи процесу.

Розглядаючи правовий моніторинг як форму державного контролю, О. Ф. Андрійко зазначає, що моніторинг може здійснюватися не лише уповноваженим органом, а й іншими суб'єктами, які за допомогою інформації, звітів у різних офіційних джерелах відстежують діяльність органів і роблять висновки щодо їі відповідності та ефективності. При цьому така діяльність не суперечить чинному законодавству, однак отримані результати можуть використовуватися при підготовці висновків, рекомендацій з метою іï оптимізаціі [7, с. 217].

Поділяючи дану думку та об'єднуючи різні погляди на розуміння правового моніторингу, I. I. Онищук зазначає, що це інноваційний прагматичний метод отримання знання про якість та ефективність нормативно-правових актів; самостійний, спеціальний вид правового контролю, що поєднує інформаційний (демонстраційний), аналітичний, інтерпретаційний, експертний, прогнозний, систематичний супровід правотворчості й правозастосування; періодичне (постійне) спостереження за динамікою й статикою правових відносин і норм, за взаємозв'язком формалізованої правотворчості та правозастосування [8, с.49].

Узагальнивши різні точки зору на розуміння правового моніторингу, слід виокремити його особливості, а саме: він здійснюється в різних сферах правового життя; забезпечується відповідними суб'єктами, з використанням різноманітних засобів (спостереження, збір, аналіз інформації); метою правового моніторингу є надання рекомендацій, висновків щодо оптимізації діяльності в правотворчості чи правозастосуванні, підвищення іiі дієвості та ефективності; об'єктом правового моніторингу можуть бути різні правові явища та процеси.

Суб'єктами правового моніторингу є органи державної влади, місцевого самоврядування, громадські організації, інститути громадянського суспільства, наукова спільнота тощо. На жаль, на законодавчому рівні не визначено суб'єктів здійснення моніторингової діяльності, що дає можливість ïx довільного тлумачення як на доктринальному рівні, так і з практичної точки зору.

Так, В. М. Косович зазначає, що доцільно провести розмежування суб'єктів моніторингу залежно від їх «моніторингових повноважень» та юридичної значущості результатів моніторингу. 
Крім того, треба брати до уваги те, що моніторинг може бути пов'язаний із підготовкою нового чи уточненням чинного нормативно-правового акта. Виходячи із зазначеного, вчений виокремлює три групи суб'єктів правового моніторингу. До першої групи він відносить усі органи сучасної української держави, наділені правом створювати нормативно-правові акти чи вносити до них зміни < .. > Наступна категорія - суб'єкти, спеціально уповноважені для проведення моніторингу ...> Третю групу становлять недержавні формування, починаючи з об'єднань громадян і завершуючи правосвідомими громадянами [9, с. 38-39].

Серед методологічного інструментарію, який використовується в процесі здійснення моніторингу, важливе місце належить діяльнісному, прагматичному, антропологічному підходам тощо, способам та прийомам формальної логіки, серед яких слід виокремити метод спостереження, аналізу та синтезу, узагальнення тощо.

Звертаючи увагу на діяльнісний підхід щодо аналізу різноманітних правових явищ, вітчизняні вчені підкреслюють, що діяльнісний підхід передбачає здійснення пояснення правового явища у нерозривній єдності з діяльністю людини. Правове явище може бути об'єктом впливу, засобом діяльності, метою або результатом, чинником зовнішнього впливу тощо, але у всіх випадках проявляється певне співвідношення людини і явища, зумовлене включенням людини у складну систему соціальних взаємодій, побудованих на правових стандартах поведінки [10, с. 125]. Погоджуючись 3 даною думкою, слід підкреслити, що саме діяльнісний підхід забезпечує можливість реалізацій поставлених завдань на різних стадіях здійснення моніторингу як в процесі збору, аналізу та збереження інформації, так і в процесі ії обробки та підготовки результатів даного виду діяльності. Поряд з цим, людська діяльність $є$ основою проведення моніторингу в різних сферах суспільних відносин та різних етапах його здійснення.

Ряд вітчизняних вчених поєднують даний підхід з прагматичним, зазначаючи, що завдання правового моніторингу - в формуванні стратегій успішного аналізу, оцінювання й прогнозування прийняття нормативно-правових актів в умовах нестабільності суспільних відносин. Відповідно, у значенні об'єкта дослідження, прагматизм вважає не просто певний фрагмент реальності безвідносно до його ролі в житті людини, але й проблематичні для людини явища або процеси природного й соціального світу $[11$, с. 52$]$. Тим самим, прагматичний підхід надає можливість оцінити ситуацію, виявити іiі проблемні сторони та розробити певну стратегію дії. При цьому необхідно враховувати мінливість, постійний динамізм соціально-правового простору.

Оскільки правовий моніторинг здійснюється певними суб'єктами, варто говорити про використання антропологічного підходу для його аналізу. В юридичній літературі підкреслюється, що такий підхід ставить людину в центр правової реальності та вивчає іiї роль в створенні цієї реальності, життєдіяльність всередині неї, взаємовплив (включаючи деструктивний вплив) людини та правової реальності [12, с. 24].

Поряд 3 даними підходами важливе місце в аналізі правового моніторингу має формально-логічна методологія. На думку зарубіжних вчених, сутність формально-логічної методології полягає в наданні формам юридичного мислення і теоретичного мислення про право самостійного значення, а також в обгрунтуванні функціонування права як формальної системи ( формально-узгодженої системи тверджень та оцінок) [13, с. 16].

3 огляду на зазначене, на певних стадіях здійснення правового моніторингу використовуються методи спостереження та аналізу. Метод спостереження відноситься до емпіричного рівня пізнання та передбачає збір і накопичення первинної інформації, що безпосередньо стосується об'єкта дослідження. Саме накопичення певної інформації надає можливість оцінити її з різних сторін.

У філософському енциклопедичному словнику підкреслюється, що в методологічному плані аналіз є таким способом дослідження об'єкта, що полягає у виокремленні його частин, властивостей, відношень тощо $з$ метою їх самостійного вивчення [14, с. 19]. Поділ досліджуваного об'єкта на складові частини сприяє виявленню особливостей досліджуваного об'єкта, зв'язків між його складовими.

Важливе місце в 3'ясуванні сутності правового моніторингу займають принципи його здійснення. 3 точки зору понятійно-категоріального апарату, принципи правового моніторингу слід розуміти як основні напрями його здійснення, що спрямовані на досягнення позитивного результату в певній сфері правової дійсності.

У процесі здійснення правового моніторингу використовується певна сукупність загальнонаукових принципів, які відрізняються за своїм змістовним наповненням та значимістю, характеризуються 
конкретністю, в їх основі закладено домінуючий тип праворозуміння. За своїм кількісним показником вони залежать від мети правового моніторингу та тих завдань, що перед ним ставляться (наприклад: принцип законності, об'єктивності, комплексності, науковості, професіоналізму тощо).

Принцип законності $\epsilon$ фундаментальним принципом будь-якого виду діяльності та $\epsilon$ засадничою основою процесу проведення правового моніторингу на різних етапах його здійснення.

Серед значущих принципів проведення правового моніторингу слід виокремити принцип об'єктивності, що грунтується на необхідності дослідження не лише з точки зору виявлення недоліків в правотворчій та правозастосовній практиці, а й позитивних сторін.

Принцип науковості правового моніторингу дозволяе використати досягнення науки з метою вдосконалення методики проведення даного виду діяльності, механізмів забезпечення та загальних підходів щодо його запровадження, що буде позитивно впливати на правотворчу та правозастосовну діяльність. У нашій державі створюються відповідні інститути, які проводять моніторинг ефективності законодавства та надають відповідні пропозиції щодо покращення його якості.

Серед спеціальних принципів правового моніторингу слід виокремити наступні: повноти, обгрунтованості, раціональності, детермінованості тощо.

Принцип повноти реалізації завдань правового моніторингу грунтується на використанні системи прийомів, послідовності дій, що надають можливість визначити якість правового регулювання в тій чи іншій сфері суспільних відносин чи охарактеризувати дієвість механізму правового регулювання.

У науковій літературі, аналізуючи принцип обгрунтованості (логічності), підкреслюється, що у відповідності до нього будь-яке знання $\epsilon$ неочевидним, носить виключно вивідний характер; у протилежному випадку знання підміняється ідеологічними установками $[15$, с. 18]. У контексті зазначеного, слід підкреслити, що принцип обгрунтованості базується як на необхідності проведення правового моніторингу, так і на аналізі результатів його проведення.

Принцип раціональності правового моніторингу насамперед передбачає вибір та використання відповідних засобів, прийомів, які повинні відповідати певній меті та визначеним завданням.

Принцип детермінованості надає можливість розкрити причинно- наслідкові зв'язки між компонентами механізму правового регулювання та правової системи загалом.

Висновки. Узагальнивши, слід зазначити, що важливим напрямом удосконалення правової сфери $є$ розробка на доктринальному рівні теоретичної моделі правового моніторингу.

Визначення сутності та змісту правового моніторингу грунтується на сучасному розумінні основних засад його здійснення і тих закономірностях, що йому властиві.

Вважаємо за доцільне визначити єдині підходи щодо розуміння методологічного інструментарію дослідження правового моніторингу.

3 метою поліпшення нормотворчого процесу та практики правозастосування, необхідно внести зміни до діючого законодавства, закріпивши процедуру проведення правового моніторингу та визначивши коло суб' єктів моніторингу, його принципи та функції.

\section{Список використаних джерел}

1. Нижник Н. Р. Правовий моніторинг як необхідна складова законотворчого процесу // Вісник Центральної виборчої комісії. - 2014. - № 2. - С. 51.

2. Онищук I. I. Сутність правового моніторингу у механізмі правового регулювання // Науково-інформаційний вісник Івано-Франківського університету права ім. Короля Данила Галицького. - Івано-Франківськ. - 2015. № 12. - C. 59 (C. 54-61).

3. Шутак І. Д. Від оцінки ефективності норм права до техніки правового моніторингу // Вісник національної академії прокуратури. - 2014. - № 3 (36). - С. 20 (С. 18-23).

4. Тихомиров Ю. А. П Правовое регулирование: теория и практика : моногр. - М. : Формула права, 2008. C. $351 .(400$ c.).

5. Великий енциклопедичний юридичний словник / За заг. ред. акад. НАН України Ю. С. Шемшученка. - К. : ТОВ «Видавництво «Юридична думка»», 2007. - С. 484. (992с.)

6. Онищук I. I. Правовий моніторинг: проблеми методології, теорії та практики : моногр. - Івано-Франківськ Дрогобич : Коло, 2017. - С. $92 .(512$ с.)

7. Андрійко О. Ф. Контроль як правова форма діяльності органів виконавчої влади // Правова держава. Вип. 20. - К. : Ін-т держави і права ім. В. М. Корецького НАН України, 2009. - С. 217. (600с.) 
8. Онищук I. I. Правовий моніторинг : проблеми методології, теорії та практики : моногр. / І. І. Онищук. - ІваноФранківськ - Дрогобич: Коло, 2017. - С. 49. (512 с.)

9. Косович В. М. Правовий моніторинг як засіб вдосконалення нормативно-правових актів України // Науковий вісник Львівського державного університету внутрішніх справ. - 2012. - № 3. - С. 38-39. (С. 31-44).

10. Методологія в праві : моногр. / [І. Безклубий, І. Гриценко, М.Козюбра та ін.]; за аг. ред. І. Безклубий. - К. : Грамота, 2017. - С. 125. (658 с. ) - (Серія «Про українське право»).

11. Онищук I. I. Правовий моніторинг : проблеми методології, теорії та практики : моногр. / I. I. Онищук. - ІваноФранківськ - Дрогобич : Коло, 2017. - С. 52. (512 с.)

12. Скакун О.Ф. Методы общие (методологические ) подходы и принципы в юридических исследованиях // Методологічні проблеми історико-правових досліджень : мат. ХХІІІ Міжнародної історико-правової конф. 24-26 вересня 2010 р., м. Алушта / ред. колегія : І.Б. Усенко (гол.), А.Ю. Іванова (відп. ред.), Л. П. Гарчева, В. Є. Кириченко, Н. М. Крестовська, І. В. Музика, Л. М. Подкоритова, О. М. Редькіна, Є. В. Ромінський, О. Н. Ярмиш. - Київ; Сімферополь : ДОЛЯ, 2011. - С. 24(620 с.).

13. Малахов В. П. Методологические и мировозренческие проблемы современной юридической теории : моногр. / В. П.Малахов, Н. Д. Эриашвили. - М. : ЮНИТИ - ДАНА: Закон и право, 2011. - С. 16. (431с.).

14. Філософський енциклопедичний словник / Під ред. В. І. Шинкарука. - К. : Абрис. - С. 19. (717 с.).

15. Малахов В. П. Методологические и мировозренческие проблемы современной юридической теории : моногр. / В. П. Малахов, Н. Д. Эриашвили. - М. : ЮНИТИ-ДАНА: Закон и право, 2011 - С. 18. (431с.).

\section{References}

1. Nizhnik N. R. Pravovij monitoring yak neobhidna skladova zakonotvorchogo procesu // Visnik Central'noï viborchoï komisiï. - 2014. - № 2. - S. 51. (S. 50-54).

2. Onishchuk I. I. Sutnist' pravovogo monitoringu u mekhanizmi pravovogo regulyuvannya // Naukovo-informacijnij visnik Ivano-Frankivs'kogo universitetu prava im. Korolya Danila Galic'kogo. - Ivano-Frankivs'k. - 2015. - № 12. S. 59 (S. 54-61).

3. Shutak I. D. Vid ocinki efektivnosti norm prava do tekhniki pravovogo monitoringu // Visnik nacional'noï akademiï prokuraturi. - 2014. - № 3 (36). - S. 20. (S. 18-23).

4. Tihomirov $\mathrm{Yu}$. A. P Pravovoe regulirovanie: teoriya i praktika : monografiya. - M. : Formula prava, 2008. - S. 351 (400 s.)

5. Velikij enciklopedichnij yuridichnij slovnik / Za zag. red. akad. NAN Ukraïni Yu.S. Shemshuchenka. - K. : TOV «Vidavnictvo «Yuridichna dumka»»", 2007. - S. 484 (992 s.)

6. Onishchuk I. I. Pravovij monitoring: problemi metodologiï, teoriï ta praktiki : monografiya. - Ivano-Frankivs'k Drogobich : Kolo, 2017. - S. 92 (512 s.)

7. Andrijko O. F. Kontrol' yak pravova forma diyal'nosti organiv vikonavchoï vladi // Pravova derzhava. - Vip. 20. K. : In-t derzhavi i prava im. V. M. Korec'kogo NAN Ukraïni, 2009. - S. 217 (600 s.)

8. Onishchuk I. I. Pravovij monitoring : problemi metodologiï, teoriï ta praktiki : monografiya / I. I. Onishchuk. - IvanoFrankivs'k - Drogobich: Kolo, 2017. - S. 49. (512 s.).

9. Kosovich V. M. Pravovij monitoring yak zasib vdoskonalennya normativno-pravovih aktiv Ukraïni // Naukovij visnik L'vivs'kogo derzhavnogo universitetu vnutrishnih sprav. - 2012. - № 3S. 38-39 (S. 31-44).

10. Metodologiya v pravi : monografiya / [I. Bezklubij, I. Gricenko, M. Kozyubra ta in.]; za ag. red.. I. Bezklubij. - K. : Gramota, 2017. - S. 125 (658 s. ) - (Seriya «Pro ukraïns'ke pravo»).

11. Onishchuk I. I. Pravovij monitoring : problemi metodologiï, teoriï ta praktiki : monografiya / I. I. Onishchuk. - IvanoFrankivs'k - Drogobich: Kolo, 2017. - S. 52. (512 s.).

12. Skakun O.F. Metody obshchie (metodologicheskie ) podhody i princypy v yuridicheskih issledovaniyah // Metodologichni problemi istoriko-pravovih doslidzhen' : materiali XXIII Mizhnarodnoï istoriko-pravovoï konferenciï 24-26 veresnya 2010 r., м. Alushta / redкolegiya : I. B. Usenko (golova), A. Yu. Ivanova (vidp. red.), L. P. Garcheva, V. E. Kirichenko, N. M. Krestovs'ka, I. V. Muzika, L. M. Podkoritova, O. M. Red'kina, E. V. Romins'kij, O. N. Yarmish. - Kiïv; Simferopol’ : «DOLYa», 2011. - S. 24(620 s.).

13. Malahov V. P. Metodologicheskie i mirovozrencheskie problemy sovremennoj yuridicheskoj teorii : monografiya / V. P. Malahov N.D. Eriashvili. - M. : YuNITI - DANA: Zakon i pravo, 2011. - S. 16 (431 s.).

14. Filosofs 'kij enciklopedichnij slovnik / Pid red.. V. I. Shinkaruka. - K. : Abris. - S. 19 (717 s.).

15. Malahov V. P. Metodologicheskie i mirovozrencheskie problemy sovremennoj yuridicheskoj teorii: monografiya / V. P. Malahov, N. D. Eriashvili. - M. : YuNITI-DANA: Zakon i pravo, 2011. - S. 18 (431s.). 


\section{Тарахонич Т. І. Правовий моніторинг як один із шляхів вдосконалення правового регулювання}

Автором розглядаються поняття категорії «моніторинг». Звернено увагу на різні підходи до розуміння сутності правового моніторингу. Аналізуються його особливості та визначаються суб'єкти правового моніторингу. Звернено увагу на принципи здійснення правового моніторингу.

Ключові слова: регулювання, правове регулювання, механізм правового регулювання, моніторинг, правовий моніторинг, суб'єкти правового моніторингу.

\section{Tarakchonych T. I. Legal monitoring as one of the ways to improve legal regulation}

The author considers the notion of the category «monitoring». The author's attention is drawn to different approaches to understanding the essence of legal monitoring.

As a result of the analysis of legal monitoring, the author determinated as essential features of legal monitoring: carring it out in various spheres of legal life; providing legal monitoring by the relevant actors; using of various means (observation, collection, analysis of information); the purpose of legal monitoring is to provide recommendations, conclusions on optimization of activity, increase its effectiveness and effectiveness; the subject of legal monitoring may be different legal phenomena and processes.

The author defines as subjects of legal monitoring: bodies of state power, local self-government, public organizations, civil society institutions, scientific community, etc.

Attention is paid to the fact that legal monitoring will promote thorough analysis and expert assessment of regulatory acts, will provide an opportunity to distinguish the priority directions of the implementation of regulatory influence, to predict the possible consequences of certain acts, promote the balance between the process of adoption of the relevant act and its implementation in practice.

The attention is also paid to the methodological tools for ensuring legal monitoring.

The principles of the implementation of legal monitoring are analyzed. In the process of legal monitoring, both general scientific and special principles are used, which differ both in their content content and in significance, namely: principles of legality, objectivity, complexity, scientific, professionalism, etc.

Among the special principles of the implementation of legal monitoring, the following principles are singled out: completeness, reasonableness, rationality, determinism, etc.

Key words: regulation, legal regulation, mechanisms of legal regulation, monitoring, legal monitoring, subjects of legal monitoring, principles of legal monitoring.

DOI: 10.33.66.3/2524-017X-2019-10-265-270 